\section{Ecosystems, Food, Agriculture, and Ethics}

\author{
Holmes Rolston III \\ Colorado State University, Fort Collins, \\ CO, USA
}

\section{Rural, Urban, and Wild}

Aristotle said that humans are by nature "political animals" (Greek polis, town, Aristotle, Politics, $1,2)$. We live in towns; we are civilized. But by nature too, we are residents on landscapes, placed in a more comprehensive community of life and life support. The rural environment is more central, more basic than the urban or wild environments. Humans may believe they have a right to a healthy and productive environment, providing needed commodities - soil, food, water, timber, and natural resources. Still, an encounter with all three dimensions - urban, rural, and wild - protects a comprehensive experience of human identity. Nature is resources, but in a deeper perspective, nature is the source that produces life, the ecosystemic life-support system.

Culture remains tethered to the biosystem. Culture depends on airflow, water cycles, sunshine, nitrogen fixation, decomposition bacteria, fungi, the ozone layer, food chains, insect pollination, soils, earthworms, climates, oceans, and genetic materials. An ecology still lies in the background of culture. In any future that we can presently envision, some sort of comprehensive or inclusive environmental fitness is required. Nature is not gone. Nor are we post-natural; rather, nature is forever lingering around. Humans and this planet have entwined destinies.

Such more comprehensive fitness is more than just a reliable supply of wheat from the breadbasket plains. People have a sense of place. Americans sing, with goose bumps, of "mountain majesties above fruited plains." All peoples need a sense of "my country," of their social communities in place on a sustaining landscape they possess in care and in love. The English love their countrysides. The promised land has been central in
Hebrew faith. Both involve a rural land tended with care and, more inclusively, an embodied sense of residence on a landscape.

Caring for landscapes goes back to Adam and Eve, to baseline human agricultural experience. The first couple was set in Eden "to till it and keep it" (Genesis 2.15). "Be fruitful and multiply, and fill the earth and subdue it; and have dominion ..." (Genesis 1.27-28). Even hunter-gatherers attempted some landscape tending, such as setting wildfires to increase grass and attract game. With the coming of agriculture, humans found tilling the good earth a toilsome blessing, reflected in the Genesis fall: "In the sweat of your face you shall eat bread" (Genesis 3.19). In the struggle for food and health, we want a naturally healthy body, but we do not want naturally healthy wild ecosystems and nothing more. We transform them agriculturally; we are stewards who garden the Earth. We "produce" food and fiber. Still, some dimensions of health pervade both wild and agricultural nature - the need for air, water, fertile and nontoxic soil, sunshine, suitable climate, and a land with promise that can be tended as a promised land.

This ancient pursuit continues. How ought humans to reside on landscapes on which they must earn a living? Some prominent figures in thinking philosophically and ecologically about agriculture are as follows: Paul Thompson (Thompson 1995, 2010); Wes Jackson, founder and president of The Land Institute in Salina, Kansas (Jackson 1994, 2010); Fred Kirschenmann, North Dakota organic farmer and also at the Leopold Center for Sustainable Development, Iowa State University (Kirschenmann 2010); and Wendell Berry (2002).

\section{Ecosystem Services}

Natural systems have provided the wider envelope in which human agriculture (and culture) functions. "Ecosystem agriculturalists will take advantage of huge chunks of what works ... the natural integrities of ecosystems worked out over the millennia" (Jackson 1985, p. 145). This surrounding milieu provides what are now called 
"ecosystem services," contributions of natural processes without which no agriculture (or culture) can flourish, but which do not classically enter into the accounting of economists. These include primary photosynthetic productivity, nutrient dispersal and cycling, pollination, food, fuel, cleansing air and water, soil renewal, and living space that is habitable and pleasant. Wild pollinators, for example, provide free pollination; in some areas honeybee colonies must be supplied to replace lost wild pollinators, at a cost of billions of dollars. Analysts who examine this may call their discipline ecological economics and distinguish it from environmental economics, which is classical economics applied to natural systems thought of as market resources. Ecological economists are holists who think more ecologically than environmental economists.

Robert Costanza led an effort to value such ecosystem services. He came up with a value of about $\$ 33$ trillion, in a range of $\$ 16$ trillion to $\$ 54$ trillion (Costanza et al. 1997; Pimm 1997). The global GDP in 1997, the year of the study, was $\$ 27$ trillion. So natural ecosystem services may exceed the entire output of the global human economy. As might be expected, the study was criticized, although critics agreed that "externalities" (as classical economists call them) - benefits from Mother Nature that belong to no one in particular and so are enjoyed for free by all - are huge. These common benefits do indeed force us to rethink what we ought to do in terms of our treatment of nature. This may also be called "translational ecology."

Ecological economists find that this goal of forever giving people more and more, however humane, drives an escalating degradation of the natural environment, undermines ecosystem services, makes it harder to grow enough food for people, reduces biodiversity, and makes the rich richer and the poor poorer. Such a humane economy is inseparably entwined with biological processes, a bioeconomics (Costanza et al. 1997; Spash 1999; Kolstad 2000; Daly and Farley 2004; Common and Stagl 2005; Millennium Ecosystem Assessment 2005).

Ecological economics thinks of the flow of energy and materials that enter and exit the economy as a kind of metabolism, digesting life nutrients, but needing environmental sources and sinks, analogous to organisms in their environment. They may worry about pushing crop yields and losing the natural fertility of the soil and replacing this with synthetic agricultural fertilizers in increasing amounts, even if this increases yields in the short term. Or they may worry about what high pesticide use is doing to the rivers and groundwater. Carrying capacity ought to govern resource use, rather than maximum exploitation. Environmental integrity and quality is as central as are production, growth, and profit.

A massive Millennium Ecosystem Assessment, sponsored by the United Nations, involving over 1,300 experts from almost 100 nations, begins: "At the heart of this assessment is a stark warning. Human activity is putting such strain on the natural functions of Earth that the ability of the planet's ecosystems to sustain future generations can no longer be taken for granted" (Millennium Ecosystem Assessment 2005, p. 5). The principal authors conclude:

We lack a robust theoretical basis for linking eco-
logical diversity to ecosystem dynamics and, in
turn, to ecosystem services underlying human
well-being. ... The most catastrophic changes in
ecosystem services identified in the MA
(Millennium Assessment) involved nonlinear or
abrupt shifts. We lack the ability to predict thresh-
olds for such changes, whether or not such a change
may be reversible, and how individuals and socie-
ties will respond.... Relations between ecosystem
services and human well-being are poorly under-
stood. (Carpenter et al. 2006)

In a review of biodiversity in ecosystem functioning, the authors conclude: "Maintaining a high proportion of biological diversity leads to efficient and stable levels of ecosystem functioning. ... Protecting biodiversity is a goal of fundamental importance and can support efforts to safeguard the intrinsic capacity of ecosystems for self-renewal, adaptive dynamics, and supporting humanity now and for generations to come" (Naeem et al. 2012, pp. 1405-1406).

Some critics reply that, moving into the Anthropocene epoch, humans are creating novel ecosystems, new combinations of species under new biotic and abiotic conditions. More than 
$80 \%$ of all people live in densely populated rural, village, and urban landscapes, what may be called "anthropogenic biomes" (Ellis and Ramankutty 2008). These critics further argue that adaptive ecosystem management approaches must explicitly acknowledge the current status and predict the future conditions of these systems. Old styles of management, which focused on removing undesirable species or conditions from ecosystems to return them to a prior condition, are no longer sufficient. We need to consider, and experiment with, novel outcomes or trajectories, rather than simply take preventative or therapeutic measures (Seastedt et al. 2008).

But ecological economists are doubtful about all this scaled-up, clever management of rural and wild lands. We have too much experience already with unexpected outcomes (e.g., kudzu, $\mathrm{CO} 2$ in the atmosphere). Maybe even in the Anthropocene, we need to keep (as Wes Jackson says) "huge chunks" of what has worked well for millennia.

\section{Farming, Food, Human, and Ecological Health}

People work to domesticate their landscapes. They have grazed and plowed fields, cleared forests, planted crops, domesticated animals, and built roads, canals, and dams. Imperial China built irrigation canals and deforested mountains. The great Southeast Asian rivers were lined with rice paddies, and their well-watered deltas have proved superb locations for the cultivation of wet rice, the staple food of much of the population. Nepalis terraced their hillsides for more, drier rice. The Hebrews, in Biblical times, terraced theirs to grow wheat. Americans had their manifest destiny to conquer their continent, planting where they could and making the rest range for their cattle. Their wheat is not native to their landscape; in fact Americans eat almost nothing that was native to North America. Soviet socialism pressed a vast plan to reinvent nature, transforming it into the obedient servant of human society. People try to get the most they can out of their agriculture.
"Domesticated nature in its simplest form means nature exploited and controlled" (Kareiva et al. 2007). Humans reshape their environments, rather than being themselves morphologically and genetically reshaped to fit their changing environments. So entering an Anthropocene epoch is just continuing what we have always been doing.

Yes, but the recent century has dramatically escalated the classical transformations. Humandominated ecosystems now cover more of Earth's land surface than do wild ecosystems (Foley et al. 2005). Nature now bears the marks of human influence more widely than ever before. Humans now consume $30-40 \%$ of all terrestrial net primary production (Vitousek et al. 1986; Imhoff et al. 2004). Humans produce more reactive nitrogen than all other terrestrial processes combined (Galloway 2004). Human agriculture, construction, and mining move more earth than do the natural processes of rock uplift and erosion (Wilkinson and McElroy 2007). These human activities alter the composition of the atmosphere, the soil, levels of biodiversity, and energy flows within food webs enough to threaten important ecosystem services. Most of life for most people takes place on landscapes that are a hybrid tapestry of nature and culture and rural, agricultural, pastoral landscapes. Humans have a huge "ecological footprint."

According to a widely held account (descending from the philosopher John Locke), value arises when nature is mixed with human "labor" or "industry," with the human labor adding most of the value. A person finds little food or shelter hiking through a forest; a farmer cuts down the trees, builds a house with the wood, and plants a vegetable garden, which must be tended or else there will be mostly weeds. Where a natural "source" can be "redirected" into channels of human interest and preference, nature is redone, "resourced," and made over into an artifact that we can use. Nature is "transformed" into a more desirable humanized form. If you prefer a biological word, human values and natural values are "symbiotic." If nature means absolutely pristine nature, totally unaffected by human activities, past or present, 
there is relatively little remaining on Earth. If culture means totally denatured, reconstructed, and civilized with no dependence on natural systems, there is none of that on Earth either. What is all over the landscapes is nature linked with human identity.

So are we to celebrate this escalation of human agricultural powers? Or should we be concerned about it? Have we passed our landscape-carrying capacity? Fewer farmers feed more people. In the United States in 1850, less than $20 \%$ of Americans lived in towns and cities. Today more than $80 \%$ are urban, and the prosperity in cities is made possible by increasingly productive mechanized agriculture on the farms, as we next see. This urbanization has also decoupled increasing numbers of humans from any direct experience of agriculture. A typical reply will be that all this is a good thing, provided only that the agriculture is sustainable, provides the population with healthy food, and continues on healthy ecosystems. One way to keep people in touch with their ecosystems is to eat local and eat organic food.

Ecosystem health is a somewhat metaphorical term, extrapolated from health as found in individual organisms, but it is a term to which people relate easily. Everybody wants to be healthy and to live in healthy places. "An ecological system is healthy and free from 'distress syndrome' if it is stable and sustainable - that is, if it is active and maintains its organization and autonomy over time and is resilient to stress" (Costanza et al. 1992, p. 9; Mistretta 2002). Biological integrity has as a baseline index the ecosystem that was originally there before human changes, the natural history, while biological health may - but need not always - require all the species that were originally there. There may be culturally introduced replacements. If there is health, these replacements will thereafter function with minimal management intervention. Generally, environmentalists dislike moving to a bioengineered agriculture that involves a constantly doctored landscape (removing toxics from streams, bringing in bees to fertilize the crops).

The 1998-1999 Malaysian Nipah virus epidemic emerged when pigs (raised for international trade) were crammed together in pens located in or near orchards. The orchards attracted fruit bats whose normal habitats had been disrupted by deforestation; their droppings contained the as yet unknown paramyxovirus and infected the pigs. The overcrowding led to explosive transmission rates and to infections in pig handlers. So a virus that was once not disruptively epidemic became so because of human disruptions of natural habitats of bats and overcrowding of pigs, driven by global commercial interests. The Malaysian government culled over one million pigs (Morens et al. 2004; Dobson 2005). Globalism sets up atypical ecological conditions favorable for invasives and pathogens. The result is human disease but the inclusive framework is agricultural and social upset of natural ecologies.

One of the classical proverbs of ecologists is that everything is connected to everything else. This proverb is proving true with links between ecological and human health, links that tie local to global events, in wild nature, agriculture, and culture. The larger framework requires thinking holistically "based on the understanding that there is only one world - and only one health" (Karesh and Cook 2005, p. 50; Rolston 2005). "Health effects ripple throughout the web of life. Health connects all species" (Tabor 2002, p. 9). Human health requires thinking in ecological contexts, increasingly in more global ones.

\section{Industrial Agriculture}

Yes, classically ecosystems did provide the wider envelope in which human systems of agriculture have functioned. But in the Anthropocene age, we have moved past that. Now and henceforth, the principal way to think of agricultural lands is as capital. Economists may speak of "capitalizing nature." Land and resources are "natural capital." We have "factory" or "corporate" farming. Farmers ought to be "industrious." Traditional agriculture was powered by muscle and blood, humans and horses, and perhaps some water power for irrigation or grinding grains. Commercial agriculture is powered by engines and gears, tractors, combines, and harvesters, in turn powered 
by fossil energy. Farming is technoscientific, with innovations in agricultural machinery, massive irrigation dams, and genetic technology, producing high-yield varieties, large-scale production, huge fields, massive harvests, patent protection, and global trade. Land is part of the machinery. There are confined animal operations (CAFOs); animals are fed enriched food, growth hormones, and antibiotics to assure maximum productivity in terms of size, taste, and sales. Traditional fertilizer was manure; now the increase comes from synthetic nitrogen and other fertilizers.

There are positive results for those in developed countries: cheaper and more plentiful food in nearby supermarkets and myriads of workers employed in the distribution system, from growers to harvesters to processors to sellers. Those in developing countries are better fed (at least they can be; many are obese). Agricultural production is over ten times what it was a century back, although the number of farmers has dropped dramatically. Now, we can support escalating populations with escalating appetites in consumption. In the 1930s, $24 \%$ of the American population worked in agriculture compared to $1.5 \%$ in 2002; in 1940, each farm worker supplied 11 consumers, whereas in 2002, each worker supplied 90 consumers (Scully 2002, p. 29). The hope is to transfer such productivity to developing nations and feed the starving world, a "Green Revolution."

But there is bad with the good. Often there are serious environmental and social costs (Gardner 2002). There is global warming from heavy use of fossil fuels. The large scale of disturbed soil for planting monocultures invites invasives, weedy plants, and exotic insects, microbes, and fungi, which must be controlled. There are increased heath risks from pesticides and other agricultural chemicals, both to wildlife and to humans. Many agriculturally used chemicals have long lifetimes; they spill over and migrate from the sites where they are applied; they build up in food chains. We woke up to this with discoveries about the unintended consequences of the pesticide DDT, Rachel Carson's "Silent Spring." In places, human breast milk has become contaminated at levels that exceed those permitted in dairy milk sold in stores. Many pesticides seem to be endocrine disrupters, disturbing reproduction. Pollution that leaks into groundwater is often impossible to remove. Pollution released into the air moves around the globe. One problem here is that agricultural uses (in contrast with industrial plants) are nonpoint sources. It is hard for regulators to pinpoint who is responsible exactly when, where, and how much. Nitrogen in fertilizer on farms in the Midwest has been traced to fish kills in the Gulf of Mexico.

The victims who live downwater or downwind never gave any free, informed consent and usually have no means of proving their damages or asserting their rights. The ill-health effects of pollution often show up first in women, especially pregnant women, and in children. The ill effects may never show up in most of the population, only in a segment of the population that is more susceptible (perhaps the senior citizens). With the long-lived pollutants, the benefits (agribusiness profits, cheap food) may be enjoyed at present, but the suffering (toxic groundwater carcinogens) is borne by future generations. The toxic effects of many of these pollutants can be much longer-lived than the human institutions set up to deal with them.

Longstanding public policies governing chemical design, production, and use need deep restructuring in the light of new science on the health and environmental effects of anthropogenic chemicals. The prevailing view is that we have to maximize yields, at risk of degrading ecosystems. Better to think more holistically. More organic farming can produce enough, healthier foods; it can even outperform chemically dependent farms in periods of drought and climatic stress (Seaman 2011). Such reforms are essential to safeguard ecosystem integrity, human health, and economic sustainability. The U.S. Congress has passed numerous laws to address these issues - notably the 1976 Toxic Substances Control Act, the 1977 Clean Water Act, the 1977 Clean Air Act, and the 1980 Comprehensive Environmental Response, Compensation, and Liability Act (CERCLA, with its Superfund). But these issues escalate when one moves from the traditional family farm to 
industrial agriculture. Corporate agriculture, with its focus on increased production, sales, and profits, is not inclined to consider the externalities, the wider and long-term consequences of its operations. The family farm could still be contained in an ecosystemic envelope; industrial farming pushes that envelope toward ecosystemic collapse.

\section{Agriculture in Developing Nations}

The Millennium Ecosystem Assessment found that "the poor are most dependent on ecosystem services and vulnerable to their degradation" (Carpenter et al. 2006). In Nepal, one of the poorest nations on Earth, there are melting glaciers in the Himalayas, resulting in glacial lake outburst floods, destroying homes and crops. At the same time monsoon rainfall is increasingly erratic, often delayed past the season for planting rice, and producing landslides that destroy agricultural terraces. This is widely ascribed to global warming, the effects felt in a nation that contributes virtually nothing to $\mathrm{CO} 2$ emissions. So far as this is true, the industrial nations are depriving poorer nations of their ecosystem services, vital to their agriculture.

The "Green Revolution" produced some positive results but came nowhere near solving the problem of feeding the world, and it is increasingly harder to bolster crop yields. Corporate agriculture, especially when faced with overproduction in developed countries, has turned to developing nations. But productivity improvements are hard to transmit there (Wilkinson 2009). This can be deliberate; high-yield varieties may be engineered so that farmers must purchase new seed each year. It can be more social or political. Often there are patent disputes or water relocations. Developing states may enter into agreements with large food corporations to grow food and may displace local farmers. There is often dispute over regulation and local corruption. Corporations may seek control over large amounts of land ("land grabbing").

Foreign businesses entering local agricultural systems can upset them as often as improve them, since they are there to make a profit, perhaps to grow crops for export (palm oil, coffee, tea, soy, shrimp). Many agricultural systems may have worked for centuries, but with recent population explosions and resulting land degradation, those in developing nations increasingly need fertilizers to boost yields - synthetic fertilizers if they can get them - but such fertilizer will be proportionately much more expensive in developing nations. African soils are often not especially fertile, and farmers there must pay two to four times the average world price for fertilizers (FAO 2008): prices are not competitive; fertilizer traders charge what they can get; and transportation is inefficient and expensive (sometimes carried on the backs of donkeys or women).

Industrial agriculture, critics often say, needs to be replaced by sustainable agriculture, and again, there are opportunities and challenges.

\section{Sustainability: Local and Global}

One powerful movement has been the turn to sustainable development, growing out of the United Nations Conference on Environment and Development in 1992. But there are two ways of thinking about sustainability. First, the economy can be prioritized: this is the usual case. Anything can be done to the environment, so long as the continuing development of the economy is not jeopardized. If economics is the driver, we will seek maximum harvests, a bioindustrial model, pushing for bigger and more efficient agriculture, so long as this is sustainable. What we must push for, according to the Royal Society of London, the world's oldest scientific society, is "sustainable intensification" of reaping the benefits of exploiting the Earth (Royal Society 2009).

In a second way of thinking, the environment is prioritized. A "sustainable biosphere" model demands a baseline quality of environment. The economy must be worked out within such a policy for environmental quality objectives (clean air, water, stable agricultural soils, attractive residential landscapes, forests, mountains, rivers, rural lands, parks, wildlands, wildlife, renewable resources). Ecosystem services have 
to be sustained. The economy must be kept within an environmental orbit. One ought to conserve the ground matrix of life. Development is desired, but even more, society must learn to live within the carrying capacity of its landscapes. The model is land as community.

The Ecological Society of America advocates research and policy that will result in a "sustainable biosphere." "Achieving a sustainable biosphere is the single most important task facing humankind today" (Risser et al. 1991). Any sustainable economic development ethic needs to be brought under a sustainable ecosystems ethic. Development concerns need to focus on natural support systems as much as they do people's needs. "Sustainable" is an economic but also an environmental term. The fundamental flaw in "sustainable development" is that it typically sees the Earth only as resource.

Philosophers may enter the dialogue to claim that sustainability of any kind needs also to be fair and just. There is nothing in either ecology or economics per se that gives either any authority or skills at making these further social decisions. Perhaps ecologists can at least make the claim that any fair and just society, over time, requires a local, regional, and planetary sustainability. The ultimate unit of moral concern is the ultimate unit of survival, and that is the biosphere on this wonderland Earth.

\section{Summary}

Food and agriculture when linked together with ecosystems raise ethical issues, in addition to technological and scientific concerns. This requires considering rural, urban, and wild landscapes; ecosystem services; human and ecological health; industrial agriculture; agriculture in developing nations; and local and global sustainability.

\section{References}

Berry, W. (2002). The art of the common-place: The agrarian essays of Wendell Berry. Washington, DC: Counterpoint.

Carpenter, S. R., et al. (2006). Millennium ecosystem assessment: Research needs. Science, 314, 257-258 (13 October).

Common, M. S., \& Stagl, S. (2005). Ecological economics: An introduction. Cambridge: Cambridge University Press.

Costanza, R., Norton, B. G., \& Haskell, B. D. (1992). Ecosystem health: New goals for environmental management. Washington, DC: Island Press.

Costanza, R., et al. (1997). The value of the world's ecosystem services and natural capital. Nature, 387, 253-260.

Daly, H. E., \& Farley, J. C. (2004). Ecological economics: Principles and applications. Washington, DC: Island Press.

Dobson, A. P. (2005). What links bats to emerging infectious diseases? Science, 310, 628-629.

Ellis, E. C., \& Ramankutty, N. (2008). Putting people in the map: Anthropogenic biomes of the world. Frontiers in Ecology and the Environment, 6(8), 439-447.

Foley, J. A., DeFries, R., Asner, G. P., et al. (2005). Global consequences of land use. Science, 309, 570-574 (22 July).

Food and Agriculture Organization (FAO). (2008). Current world fertilizer trends and outlook to 2011/2012. Rome: Food and Agriculture Organization of the United Nations. ftp://ftp.fao.org/agl/agll/docs/ cwfto11.pdf

Galloway, J. N. (2004). The global nitrogen cycle. In W. H. Schlesinger (Ed.), Biogeochemistry (Vol. 8). In H. D. Holland \& K. K. Turekian. (Eds.), Treatise on geochemistry. Oxford: Elsevier-Pergamon.

Gardner, B. L. (2002). American agriculture in the twentieth century: How it flourished and what it cost. Cambridge: Harvard University Press.

Imhoff, M. L., Bounoua, L., Ricketts, T., et al. (2004). Global patterns in human consumption of net primary production. Nature, 429, 870-873.

Jackson, W. (1985). New roots for agriculture. Lincoln: University of Nebraska Press.

Jackson, W. (1994). Becoming native to this place. Lexington: University Press of Kentucky.

Jackson, W. (2010). Consulting the genius of the place: An ecological approach to a new agriculture. Berkeley: Counterpoint. 